Original Research

\title{
TTF-1-Expressing Supratentorial Embryonal Tumors (PNET): A Clinicopathologic Study of Two Cases and Literature Review of TTF-1- Positive Primary Brain Tumors
}

Michele Bisceglia ${ }^{1,}{ }^{*}$, Stefano Pizzolitto ${ }^{2}$, Tullio Parracino ${ }^{3}$, Giovanna De Maglio ${ }^{2}$, Elena Minenna

${ }^{4}$, Serena D'Agostini ${ }^{5}$, Carlos A. Galliani ${ }^{6}$

1. Anatomic Pathology, School of Biomedical Sciences, Etromapmax Pole, Lesina (FG), Italy; EMail: bismich@alice.it

2. Department of Pathology, Azienda Sanitaria Universitaria Integrata di Udine, Udine, Italy; EMails: stefano.pizzolitto@asuiud.sanita.fvg.it; giovanna.demaglio@asuiud.fvg.it

3. Department of Radiology, IRCCS "Casa Sollievo della Sofferenza" Hospital, San Giovanni Rotondo (FG), Italy; E-Mail: t.parracino@operapadrepio.it

4. Department of Medical and Surgical Sciences, University of Foggia, Foggia, Italy; E-Mail: elena.minenna@unifg.it

5. Department of Neuroradiology, Azienda Sanitaria Universitaria Integrata di Udine, Udine, Italy; E-Mail: serena.dagostini@asuiud.fvg.it

6. Department of Pathology, Children's Minnesota, Minneapolis \& St. Paul, MN, USA; E-Mail: Carlos.Galliani@childrensmn.org

* Correspondence: Michele Bisceglia; E-Mail: bismich@alice.it

Academic Editor: Antonio Meola

Special Issue: $\underline{\text { Tumors of the Central Nervous System }}$

OBM Neurobiology

2018 , volume 2 , issue 4

doi:10.21926/obm.neurobiol.1804016
Received: October 7, 2018

Accepted: November 2, 2018

Published: November 14, 2018

\begin{abstract}
Thyroid transcription factor 1 (TTF-1) is a nuclear polypeptide and a tissue-restricted member of the homeobox protein family that, when attached to DNA, plays a crucial role in regulating the expression of select genes during early embryonic development of the thyroid, lung, and brain.
\end{abstract}

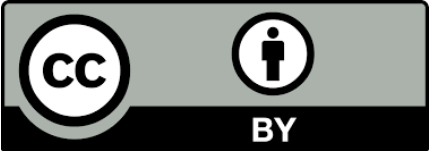

(C) 2018 by the author. This is an open access article distributed under the conditions of the Creative Commons by Attribution License, which permits unrestricted use, distribution, and reproduction in any medium or format, provided the original work is correctly cited. 
As often happens, the initial enthusiasm for the diagnostic value of TTF-1 as a selective immunohistochemical marker of lung and thyroid tumors began to dwindle, due to its detection in tumors arising from other organs.

TTF-1-expressing primary brain tumors arising in the $3^{\text {rd }}$ ventricle were first reported in 2004. More recently, tumors arising from the posterior hypophysis (pituicytomas, granular cell tumors of the sellar region, and spindle cell oncocytomas of the pituitary gland) as well as chordoid gliomas of the third ventricle and subependymal giant cell astrocytomas have been proven to be TTF-1 immunoreactive.

We present for the first time the expression of TTF- 1 in two primary embryonal tumors (PNETs) of the anterior basal brain. One was in a 6 $1 / 2$-year-old female and the other in a 36year-old female.

General surgical pathologists and neuropathologists should be aware of the potential TTF-1 expression in tumors of the ventral forebrain.

\section{Keywords}

Thyroid transcription factor 1 (TTF-1); brain tumor; primitive neuroectodermal tumor (PNET); central nervous system (CNS); embryonal CNS tumor

\section{Background and Aims}

Human thyroid-specific transcription factor-1 (TTF-1), also known as thyroid-specific enhancerbinding protein (T/EBP or NKX2.1), is a 371 amino acid-long polypeptide (with a molecular weight of 38 to $40 \mathrm{kDa}$ ), and is a homeodomain-containing transcription factor of the NK-2 family [1]. Human TTF-1 is encoded by a single gene located on chromosome 14 and is organized into two or three exons and one or two introns [1, 2]. The known molecular targets of TTF-1 in the thyroid are thyroglobulin, thyroid peroxidase, and thyrotropin receptor genes [1, 2].

TTF-1 expression has also been found in the bronchioloalveolar epithelium of the lung, where it similarly functions as a transcriptional activator of specific genes, such as alveolar type II cell surfactant protein genes and the bronchiolar Clara cell secretory protein gene [1, 3-7]. It has also been observed in the ventral forebrain where the responsive genes are mostly unknown. TTF-1 expression in the central nervous system (CNS) has been documented in the ventral neuroepithelium of the anterior wall of the third ventricle and hypothalamic areas, including the infundibulum, which is the site of derivation of the neurohypophysis $[1,3,4,8,9]$.

TTF-1 plays a fundamental role in organogenesis by regulating the expression of additional genes that are directly involved in development and differentiation [6, 10-12]. Experimental studies have demonstrated that in T/EBP knock-out homozygous mice, the embryonic development of the thyroid, lung, hypothalamus, pituitary, and globus pallidus is dramatically impaired [1, 3, 10, 13-16]. Limited information exists on the regulation of TTF-1 gene expression by hormones, cytokines, and other biological agents [2].

For many years, TTF-1 has been extensively used for diagnostic purposes in surgical pathology as a lineage-specific immunohistochemical marker, most often for primary and secondary tumors of the lung and thyroid [17-21], and especially of neuroendocrine lineages [22]. 
Two monoclonal antibodies to TTF-1 are commercially available: the SPT24 clone (Novocastra Laboratories, Newcastle Upon Tyne, UK), which is currently known to be more sensitive than the other [23], and the 8G7G3/1 clone (Dakocytomation, Carpinteria, CA, USA), which conversely, is considered more specific [21, 24].

Over time, many reports soon documented its sporadic or frequent expression in tumors from other sites, such as the gastrointestinal tract, breast, urinary bladder, and prostate. The majority of these tumors are of neuroendocrine nature, mainly small-cell carcinomas [22, 25-29]. In a lesser proportion, others belong to a wide variety of cell and tissue types [23, 30-35], including nephroblastomas [29]. Subsequently, nuclear TTF-1 immunostaining was documented in primary brain tumors as well [36-46].

Therefore, the presence of TTF-1 immunoreactivity in a metastatic small cell (neuroendocrine) carcinoma cannot by itself be used as a sign of pulmonary or thyroidal origin, and in this situation, an extrapulmonary source cannot be excluded [21, 23, 29]. Likewise, even when dealing with metastatic non-small cell carcinoma, the possibility of a remote deposit from other sources (such as breast, uterus, gastrointestinal tract, and others) cannot be ruled out based on the sole TTF-1 immunopositiviy in tumor cells $[21,23,29]$. This occurs also with the $8 G 7 G 3 / 1$ clone, albeit in a lower percentage of cases, in comparison with the SPT24 clone [21].

In 2011, Galliani and Bisceglia analyzed TTF-1 expression with the 8G7G3/1 clone in a series of 117 varied embryonal tumors [47], excluding nephroblastomas, which represented the subject of a previous and separate study [29]. This large series of embryonal tumors, both in children and adults [47], considered 92 tumors from extra-CNS sites and 25 primitive CNS neuroectodermal tumors (cPNETs, which are currently referred to as CNS-embryonal tumors, according to 2016 WHO classification of tumors of the central nervous system [48]).

Of the extra-CNS embryonal tumors, 28 were peripheral PNETs (i.e., members of the Ewing's sarcoma family), 14 were peripheral thoracoabdominal neuroblastomas, 18 were embryonal rhabdomyosarcomas, 16 were alveolar rhabdomyosarcoma, 5 were desmoplastic small round cell tumors, 4 were hepatoblastomas, 4 were pleuropulmonary blastomas, 1 was a paraganglioblastoma, 1 was a pancreatoblastoma, and 1 was an undifferentiated liver sarcoma. None of these expressed immunoreactivity for TTF-1 [47].

Moreover, the 25 central PNETs of our series included 14 infratentorial PNETs (medulloblastomas), 4 supratentorial PNETs, 1 inframedullary PNET, 3 supratentorial neuroblastomas (including 1 olfactory neuroblastoma), 2 pineoblastomas, and 1 retinoblastoma [47]. Of all these tumors, just one pediatric suprasellar (classic) PNET from 2008 expressed TTF-1, while all the rest failed to do so.

In the same year, another case of a TTF-1-expressing PNET in a 36-year-old woman was observed during routine work. This latter case was histologically diagnosed as PNET with anaplastic features, as previously reported by other authors $[49,50]$.

We report herein the findings as well as the clinical and morphological features of these two cases of TTF-1 immunoreactive suprasellar and parasellar PNETs, one in a female child and the other in a young lady, respectively, taking the opportunity to review the entire rubric of TTF-1 immunopositive primary brain tumors reported in the literature. 


\section{Case Reports}

\subsection{Case 1}

Computed tomography (CT) scan and magnetic resonance imaging (MRI) of the head performed on a $61 / 2$-year-old girl, who was brought in semiconscious state to the emergency department of the Casa Sollievo della Sofferenza hospital in San Giovanni Rotondo (Italy) in 2008, disclosed an $8.0 \mathrm{~cm}$ midline, contrast-enhancing, suprasellar tumor that protruded into the $3^{\text {rd }}$ ventricle and encased the intracranial carotid arteries (Figure $1[\mathrm{~A}-\mathrm{F}]$ ). The suprasellar tumor was partially resected.
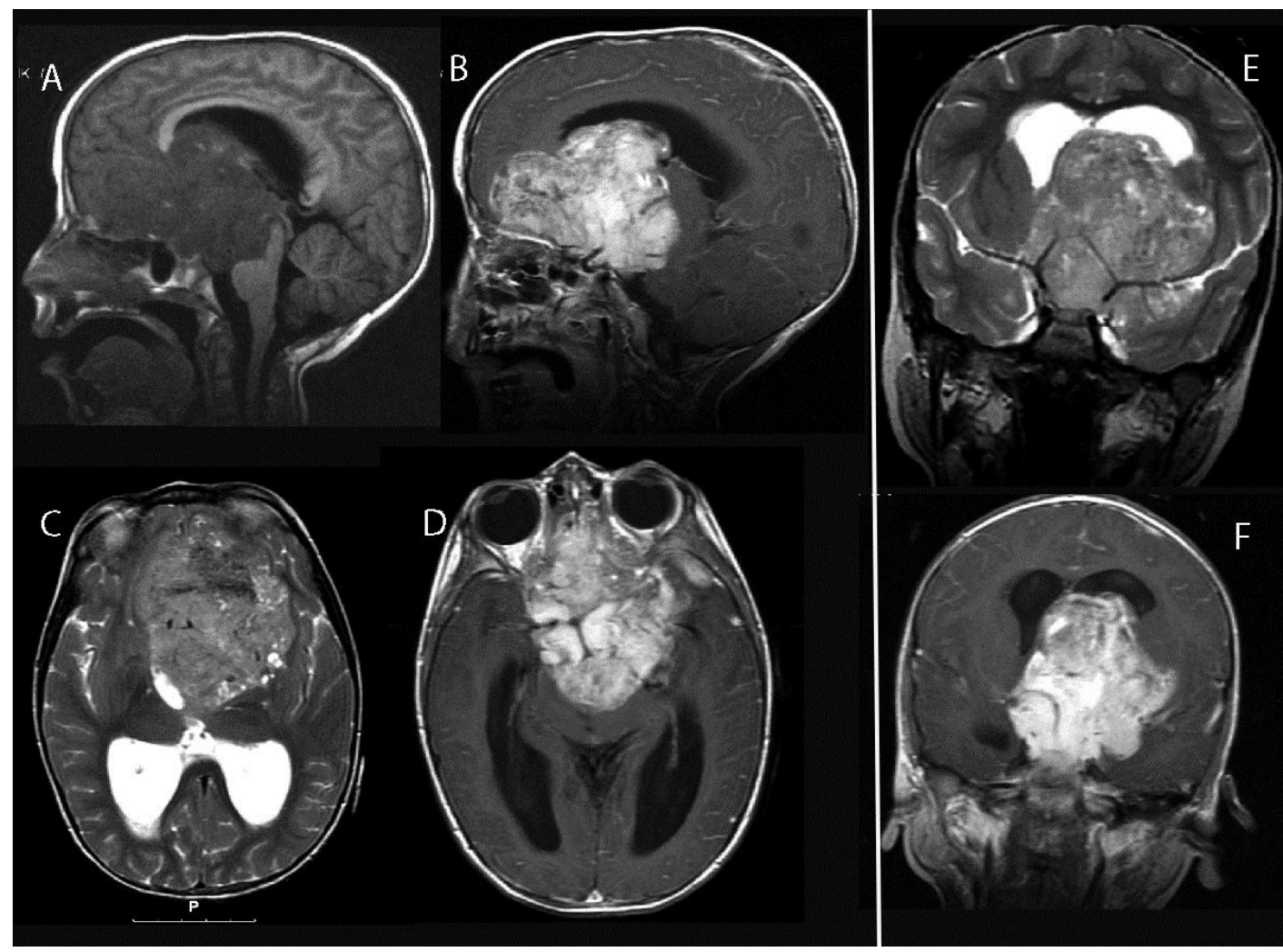

Figure 1 (A-F) MRI study. (A) Spin-echo T1w without contrast: sagittal scan. A huge isointense $\sim 8.0 \mathrm{~cm}$ midline tumor invades the frontal lobe, genu of corpus callosum, and mesencephalon. (B) Spin-echo T1w with contrast: sagittal scan. Suprasellar tumor invades the left lateral ventricle. The 3rd ventricle is filled with tumor, thus unrecognizable. (C) Fast spin-echo T2-w without contrast: axial scan. Large ventral brain tumor with heterogenous intensity. (D) Spin-echo T1w with contrast: axial scan. Contrast-enhancing suprasellar tumor invades the 3rd ventricle. (E) T2w: coronal scan. Dilated lateral ventricles and mid cerebral arteries are elevated by the underlying tumor. (F) T1-w with contrast: coronal scan. Suprasellar tumor occupying the 3rd ventricle, partly invading the left lateral ventricle.

Histopathologically, an intraoperative frozen section was interpreted as a small round cell tumor of unspecified origin (Figure 2A). Permanent sections confirmed a small round blue cell 
neoplasm with perivascular pseudorosettes and Homer Wright rosettes, brisk mitotic and apoptotic activity, and foci of necrosis (Figure $2[B-G]$ ).

Immunohistochemically, the tumor cells were focally positive for synaptophysin, neurofilaments, and glial fibrillary acidic protein (GFAP), and negative for S100 protein, desmin, myogenin, cytokeratins (wide spectrum), CD45, and CD99. INI-1 was normally expressed. Proliferation index, as assessed by Ki-67/MIB-1, was 50\%.

Since a study of TTF-1 expression in small round cell tumors from any location was in progress, this case was included as well.

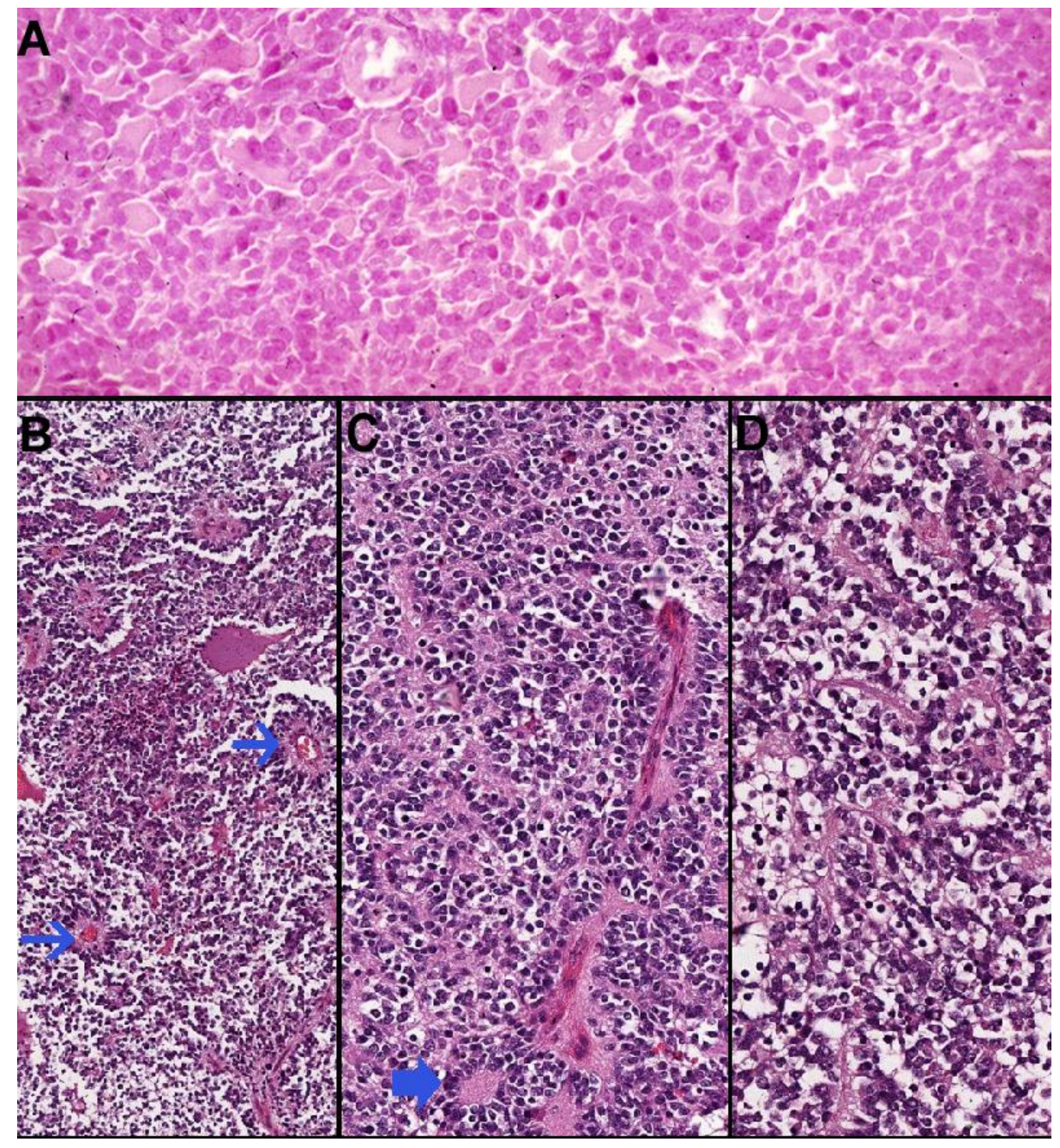

Figure 2 (A-D) Histopathology. (A) Frozen section preparation, Hematoxylin \& Eosin stain. Patternless sheets of monotonous neoplastic small-round-cells of indeterminate origin. (B) Paraffin embedded permanent section, H\&E, low-power view. Embryonal tumor with early spotty necrosis in the center, and perivascular pseudorosettes narrow arrows. (C) H\&E, higher magnification. Small, undifferentiated tumor cells with perivascular alignment (not indicated), and Homer Wright rosettes (broad arrow). (D) Neoplastic cells with cytoplasmic pseudoclearing, pericellular artifact. 


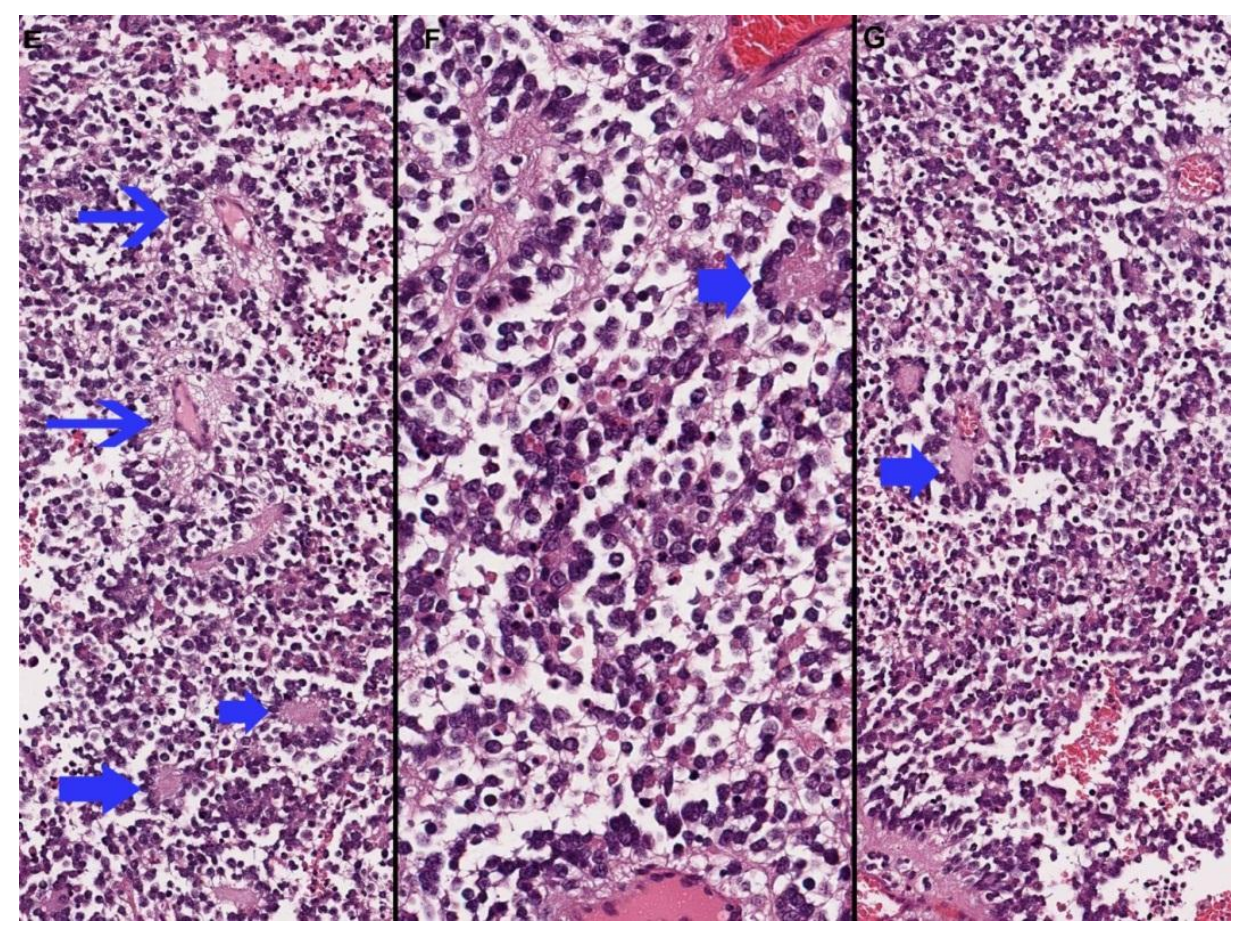

Figure 2 (E-G) Histopathology (cont'd). Paraffin embedded permanent sections, Hematoxylin \& Eosin stain. Embryonal tumor exhibiting perivascular pseudorosettes (narrow arrows) and Homer Wright rosettes (broad arrows).

TTF-1 was detected according to the following procedure. Antigen retrieval was heat-induced on deparaffinized $4 \mu \mathrm{m}$ sections for two cycles each of 15 minutes in $10-\mathrm{mM}$ citrate buffer $(\mathrm{pH}=6)$ using a $360 \mathrm{~W}$ microwave oven. Immunostaining was performed with the labelled streptavidinbiotin peroxidase complex system (LSAB2), using the monoclonal 8G7G3/1 (Dako) antibody to TTF1 diluted $1: 30$ in a Dako Autostainer (Dako). Endogenous peroxidase was blocked, diaminobenzidine was employed as a chromogen, and counter-stain was done with hematoxylin. The sections were evaluated by two observers and judged to be positive for TTF- 1 in at least $50 \%$ of the nuclei of the tumor cells (Figure $3[A-B]$ ).

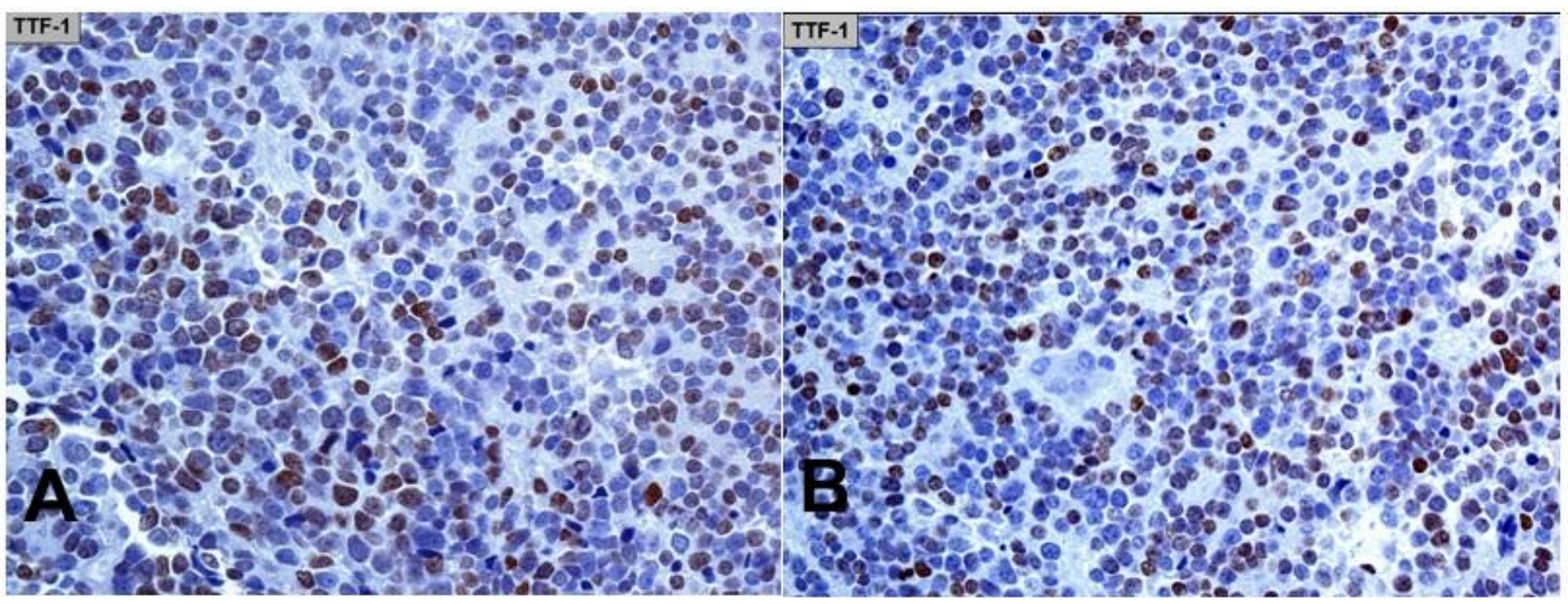

Figure 3 (A-B) TTF-1 immunohistochemistry (monoclonal antibody 8G7G3/1). Nuclear expression in at least $50 \%$ of the tumor cells. 
Diagnosis: central PNET with early neuroblastic differentiation and TTF-1 expression.

Follow-up: The patient received craniospinal radiation and chemotherapy, including temozolamide and VP-16. Imaging performed one year after the partial resection revealed residual tumor. The patient died of her disease 20 months after the diagnosis.

\subsection{Case 2}

During CT and MRI investigation for intracranial hypertension, a 36-year-old female who was admitted in 2011 at the Santa Maria della Misericordia hospital in Udine (Italy) was found to have a huge ventral brain tumor involving the diencephalon (Figure 4 [A-D]). Subtotal tumor resection was performed.

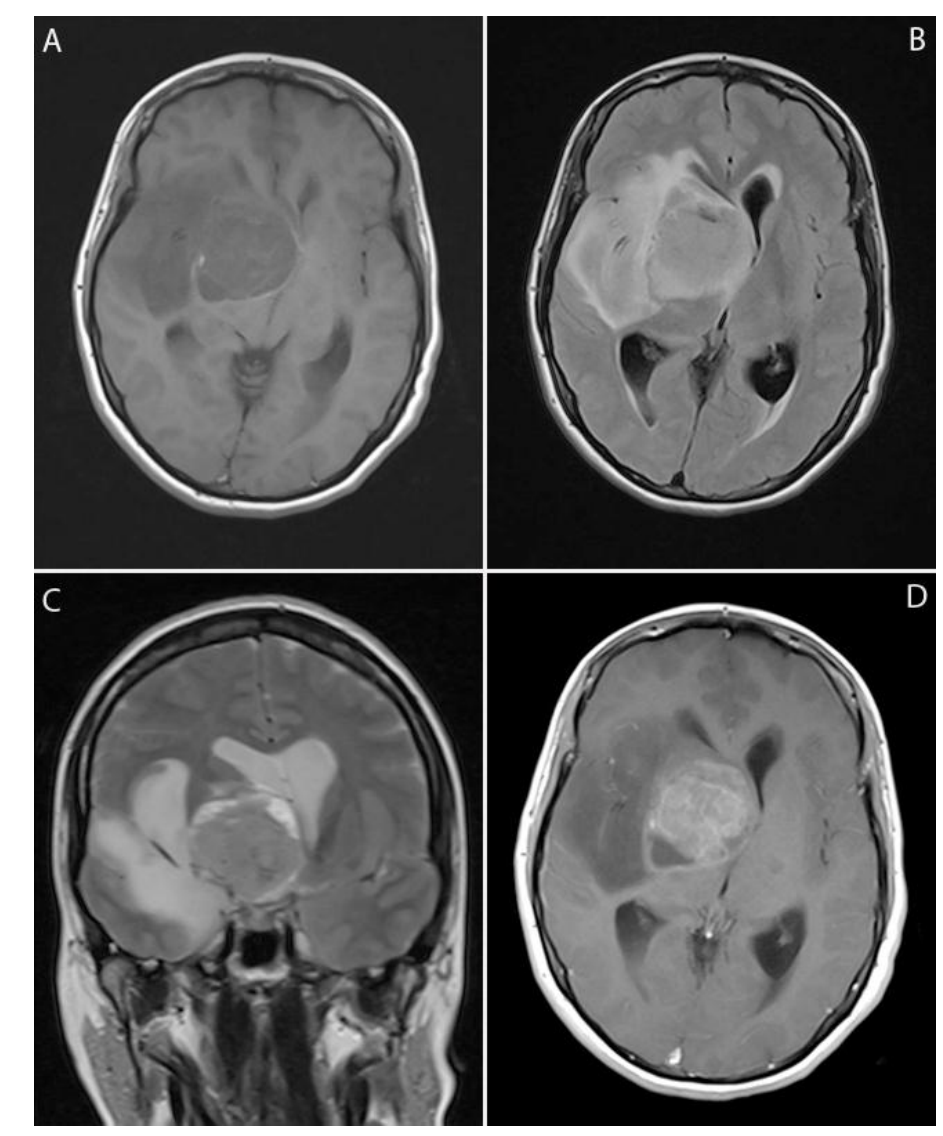

Figure 4 (A-D) MRI study. (A) A $\sim 4.0 \mathrm{~cm}$ intra-axial, suprasellar, expansile mass involving the hypothalamus and right thalamus. The tumor is solid with heterogenous intensity, pseudocystic areas, rounded to infiltrative margins, and exhibits a peripheral rim of edema. No necrosis is noticed. There is weak contrast enhancement in D. The right middle cerebral artery is encased by tumor, but retains normal blood flow. The 3rd ventricle is filled with tumor, and there is mass effect with displacement of the surrounding structures, including the optic chiasm. No intrasellar involvement is seen. (A) MRI TSE T1w: axial scan without contrast; (B) MRI FLAIR: axial scan without contrast; (C) MRI TSE T2w coronal scan without contrast; (D) MRI SE T1w gadolinium with contrast.

Histopathologically, the tumor was highly cellular and comprised of small round blue cells sprinkled with large, pleomorphic, hyperchromatic, and anaplastic-appearing nuclei; a high 
mitotic-apoptotic index; and contained foci of necrosis. No rosettes or perivascular pseudorosettes were observed (Figure $5[\mathrm{~A}-\mathrm{H}]$ ).

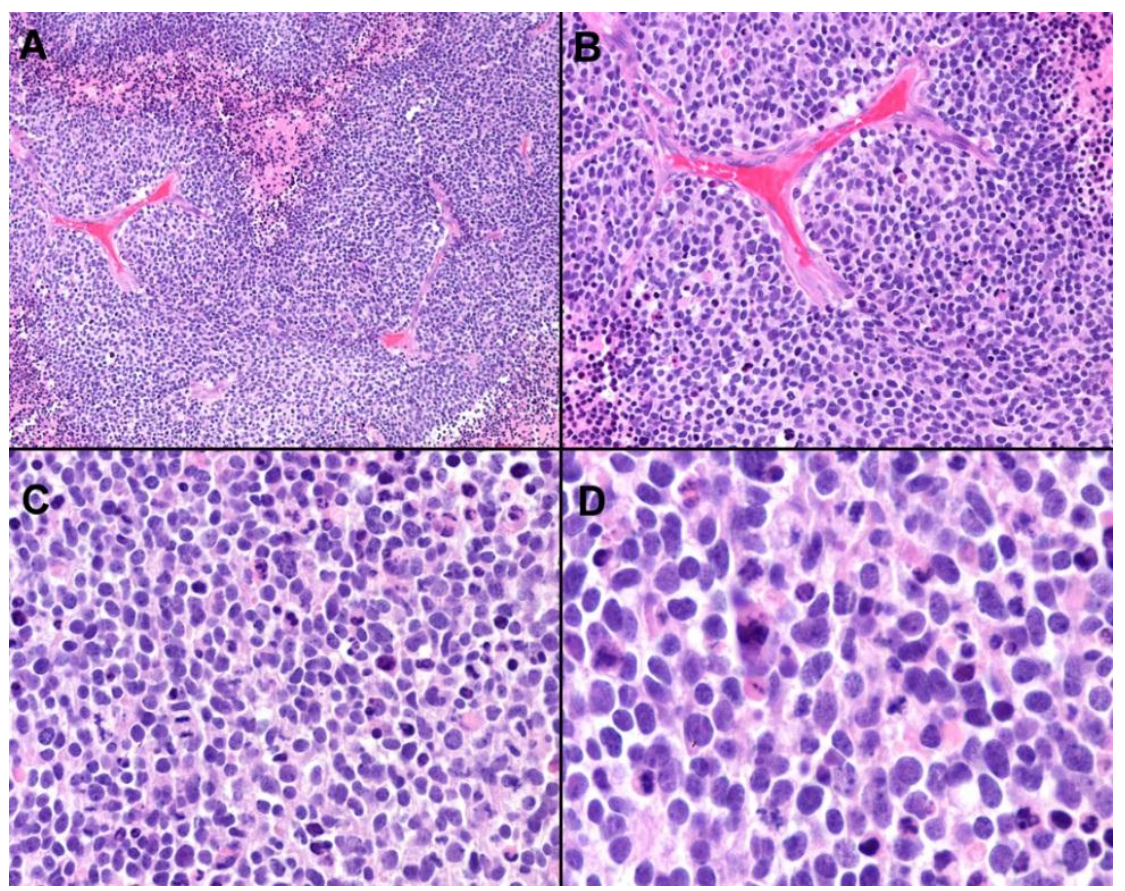

Figure 5 (A-D) Histopathology. (A-B) Small round-blue cell tumor, showing microgeographical foci of necrosis in A (center towards the top) and $\mathrm{B}$ (top right and bottom left). (C-D) Higher power views. Several mitotic and apoptotic figures are seen. (Hematoxylin \& Eosin stain on paraffin embedded tissue sections).

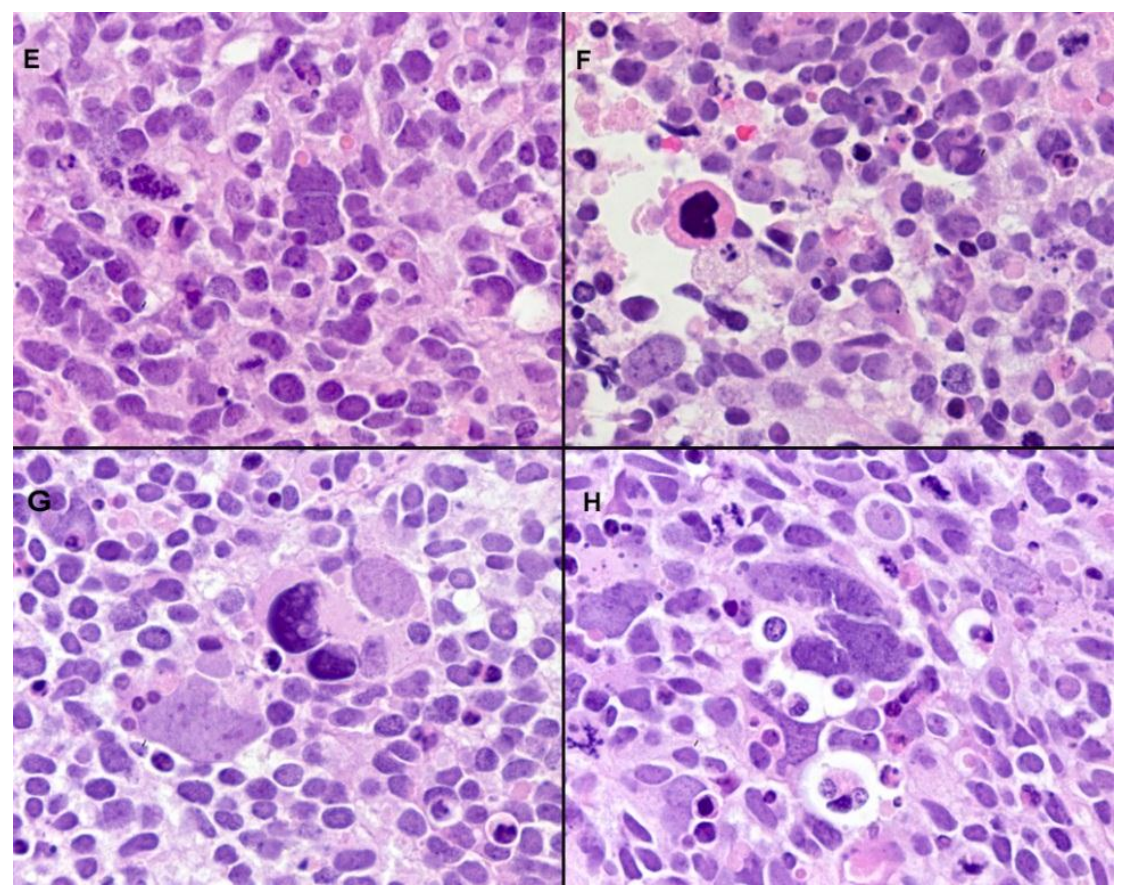

Figure 5 (E-H) Histopathology (cont'd). This tumor also showed throughout a variable range of anaplastic features with "bizarre giant cells", apoptotic bodies, necrosis, and atypical mitoses, similar to the description made in the literature in two PNETs of adults (the reader is advised to see panels 5 and 8 of Figure 5 in ref. 50). 
Immunohistochemically, the tumor cells showed diffuse cytoplasmic immunoreactivity for synaptophysin and NSE. Focal immunopositivity in a certain percentage of cells was observed for nestin, Neu-N, and neurofilament proteins with mean values of $30 \%, 15 \%$, and $30 \%$, respectively (Figure 6 [A-D]). Conversely, CD45, CD99, S100 protein, GFAP, chromogranin A, cytokeratin 7, cytokeratin 8 (CAM5.2), desmin, and myogenin were all negative. p53 was diffusely expressed in the nuclei of tumor cells. The Ki67 tumor proliferation fraction assessed with the MIB-1 antibody was very high (over 90\%).

TTF-1 nuclear expression was detected with immunostaining using the monoclonal 8G7G3/1 antibody diluted 1:50 in the EnVision FLEX discovery system (Dako, Glostrup, Denmark) after heatinduced pretreatment of deparaffinized $4 \mu \mathrm{m}$ tissue sections in citrate buffer $(\mathrm{pH}=6.1)$ for antigen retrieval. Endogenous peroxidase activity was blocked, diaminobenzidine was used as a chromogen, and hematoxylin as a counterstain. Then, the immunoreactivity was evaluated by two observers, and judged to be positive in the nuclei of $50 \%$ of tumor cells (Figure 6 [E-F]).

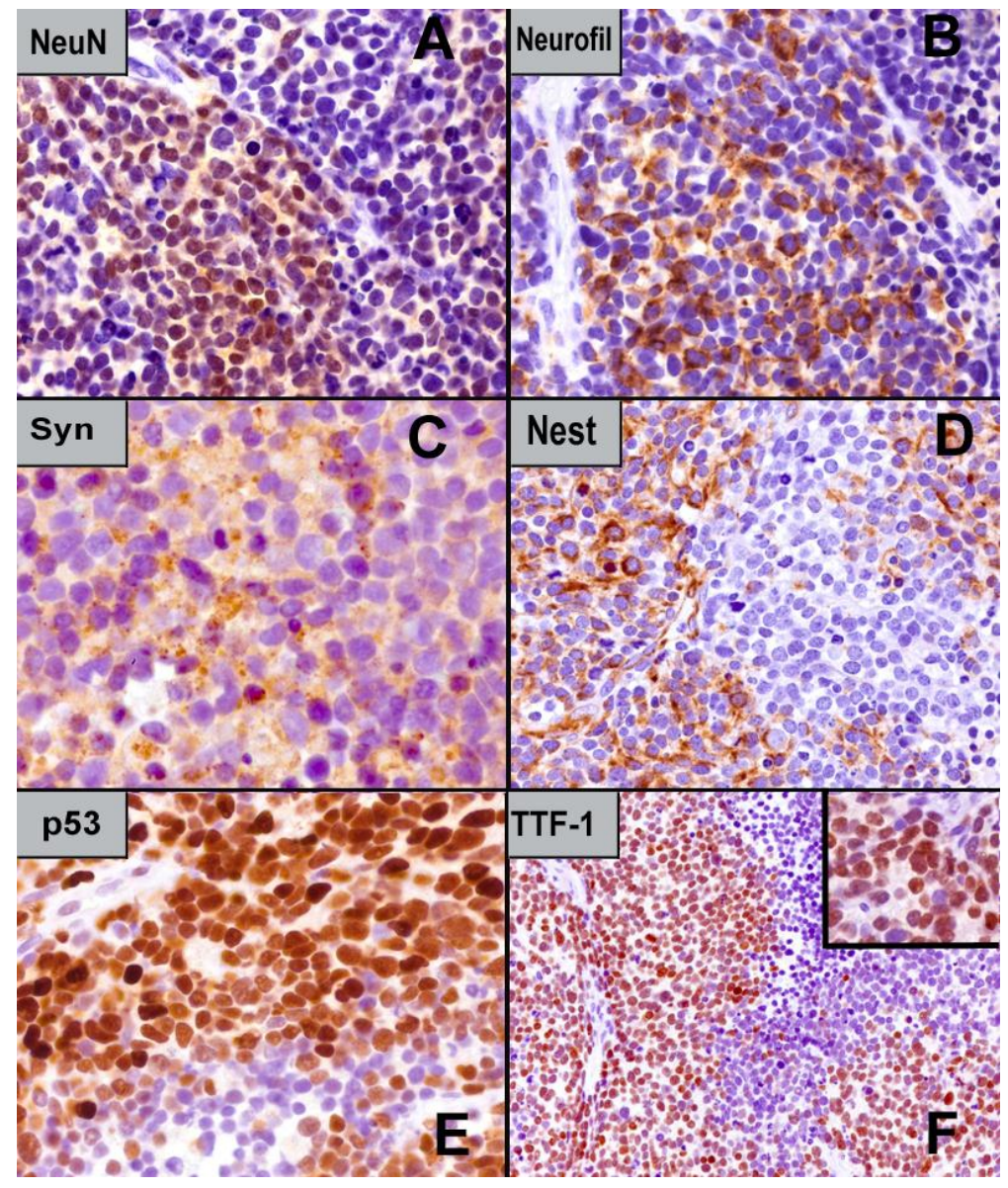

Figure 6 (A-F) Immunohistochemistry. (A) [Neu N] Nuclear immunoreactivity in 50\% of tumor cells. (B) [Neurofilament proteins] Cytoplasmic immunostaining with perinuclear crescentic positivity in 50\% of tumor cells. (C) [Synaptophysin]. Diffuse cytoplasmic immunopositivity. (D) [Nestin] Cytoplasmic immunoreactivity in over $50 \%$ of tumor cells. (E) [p53] Variably strong nuclear expression. (F) [TTF-1] Intranuclear expression in over $50 \%$ of nuclei of tumor cells (monoclonal antibody 8G7G3/1). Inset: detail of immunoreactivity. Note: The estimated percentage of positive cells for panels $A-D$, and panel $F$, is displayed on the pictured tumor fields: the mean value for each marker is given in the text. 
For the sake of completeness, Wilms' tumor 1 protein (WT1), which is a transcriptional activator or repressor factor that controls genes that mediate the epithelial-to-mesenchymal transition and shuttles between the nucleus and cytoplasm, was also included in this extensive immunohistochemical analysis, revealing focal cytoplasmic positivity ( $40 \%$ of tumor cells) with a partial crescentic perinuclear pattern.

Diagnosis: central PNET with early neuroblastic differentiation and TTF-1 expression.

Follow-up: follow-up was lost on the patient. It is presumed that she received radiation treatment in another institution. The patient died of tumor-related causes 2 years and 10 months after diagnosis.

\section{Discussion}

In the experimental rodent CNS model, TTF-1 expression was detected in the ependymal and subependymal cells of the ventral neuroepithelium of the $3^{\text {rd }}$ ventricle, including neurons of select hypothalamic nuclei, astrocytes of the median eminence, pituicytes of the infundibular stalk and neurohypophysis, and in the adjacent extrahypothalamic (rat) suprachiasmatic nucleus and subfornical organ $[3,12,15,51,52]$.

In 2004, Zamecnik et al. used monoclonal antibodies against TTF-1 (using the 8G7G3/1 clone) and documented TTF-1 expression in two cases of ependymomas (one grade II and one grade III, both localized in the $3^{\text {rd }}$ cerebral ventricle in a 5-year old boy and in a 12-year old girl, respectively) out of 73 primary brain tumors investigated, including 33 astrocytic tumors of various grades, 27 classic ependymomas (11 grade II and 16 grade III), 7 medulloblastomas, and 3 gangliogliomas [36].

In 2006, Prok and Prayson used the same 8G7G3/1 clone and studied 50 cases of glioblastomas but did not prove immunopositivity in any [37]. In 2007, Galloway and Sim investigated TTF-1 expression in 28 cases of glioblastomas using both clones currently available (the 8G7G3/1 and SPT24): 14 glioblastomas proved positive when SPT24 clone was used, while no case was immunopositive with the 8 G7G3/1 clone [38]. Galloway and Sim first questioned the specificity of TTF-1 immunopositivity in their 14 glioblastomas [38].

In 2009 , Lee et al., using the 8 G7G3/1 clone, studied a series of five pituicytomas and four granular cell tumors arising from the posterior lobe of the pituitary, all of which expressed TTF-1 [39].

Again in 2011, Kristensen et al. used the SPT24 clone and demonstrated TTF-1 immunoreactivity in approximately $18 \%$ of high-grade astrocytic and oligodendrocytic gliomas (10 immunopositive cases out of 56 grade III to grade IV tumors), and no immunoreactivity in all 47 low-grade astrocytic and oligodendrocytic tumors [40]. Additionally, they also found TTF-1 immunopositivity in one of three central neurocytomas, one of 18 ependymal tumors, and one of five choroid plexus tumors, but no positivity was observed in any of four pineal tumors, 11 meningiomas, eight PNETs, or four mixed glio-neuronal tumors [40]. However, Kristensen et al. could not document any immunoreactivity in any of the above brain tumors when the clone used was $8 \mathrm{G} 7 \mathrm{G} 3 / 1$ [40].

In 2014, similar results to Kristensen's study were experienced by Unal et al., who analyzed 45 primary brain tumors (one grade I, seven grade II, four grade III, 20 grade IV astrocytic tumors, 9 meningiomas, two oligodendrogliomas, one schwannoma, and one medulloblastoma) with both 
monoclonal antibodies. These authors found four high-grade astrocytic tumors to be TTF-1 immunopositive when using the SPT24 clone, while no case was positive using the other clone [41].

All the above brain tumors investigated for TTF-1 expression were from several various areas and sites of the encephalon. Therefore, based on our own and others' experiences [21, 24], it must be said that the SPT24 clone is more sensitive but less specific than the $8 \mathrm{G} 7 \mathrm{G} 3 / 1$ clone, even in brain tumors pathology [36-38, 40, 41].

During the last decade, nuclear TTF-1 immunostaining has been specifically documented in most (if not all) sellar/suprasellar neurohypophyseal tumors studied.

In 2009, Lee et al. used the 8 G7G3/1 clone and studied a series of five pituicytomas and four granular cell tumors arising from the posterior lobe of the pituitary gland: all of these neurohypophyseal tumors expressed TTF-1 [39].

In 2010, Bisceglia and Galliani also investigated seven differentiated brain tumors (two central neurocytomas, three pineocytomas, and four subependymomas located either in a lateral or the $4^{\text {th }}$ ventricle), but did not observe any immunostaining in any of them [53].

In 2013, Mete et al. investigated seven spindle cell oncocytomas, four pituicytomas, and three granular cell tumors, all of which showed nuclear positivity for TTF-1 (using the SPT24 clone). On the basis of the same immunohistochemical profile, including several other markers, these authors also concluded that these three groups of tumors likely share a common histogenesis, and all are variants of pituicytoma [54]. This interpretation was already anticipated [55], concordant with reviews of the subject [56-58], which proposed nomenclature of spindle cell oncocytoma as oncocytic pituicytoma, granular cell tumor as granular cell pituicytoma, and sellar ependymoma as ependymal pituicytoma [56].

TTF-1 is considered to be an excellent marker of (both fetal and adult) pituicytes, the specialized glial cells of the neurohypophysis [39], although the matter of a common histogenesis for the entire group of TTF-1 immunopositive sellar/parasellar tumors (i.e., pituicytomas, granular cell tumors of the sellar region, spindle cell oncocytomas, and sellar ependymomas) is still not definitely settled [59-63].

Three separate cases of TTF-1 immunopositive mixed pituicytoma, one with classic pituicytoma, spindle cell oncocytoma, and an ependymal component [56], a second with epithelioid oncocytic, follicle formation, and ependymal differentiation [61], and a third with spindle cell oncocytoma and (pituicytic) ependymal differentiation [64], point to unify their derivation. Nuclear TTF-1 expression was documented in the ependymal component [64] (also called "follicle formation/ependymal differentiation" or "follicle-like organotypic differentiation") in the classical pituicytomatous [56,61] and in the spindle cell oncocytomatous component [64]. TTF-1 expression was detected using the monoclonal SPT24 antibody in two different cases $[61,64]$. In a third case, the antibody used was not specified by the authors (presumably SPT24) [56].

In the $4^{\text {th }}$ edition of the 2017 World Health Organization classification of pituitary tumors [65], all TTF-1 positive, non-neuroendocrine, low-grade (WHO grade I) sellar/suprasellar tumors of the posterior hypophysis (and infundibular stalk) are included and discussed, and subsequently reiterated and emphasized [66-68].

Parenthetically, on reviewing this subject, we found that approximately 70 cases of (classic) pituicytomas [46, 57], 25 cases of spindle cell oncocytomas [62], approximately 100 cases of sellar 
granular cell tumors [58], and 9 cases of intrasellar ependymomas $[69,70]$ have been recorded in literature thus far.

Furthermore, in 2014, Michotte et al. reported for the first time TTF-1 expression (with the 8 G7G3/1 clone) in a chordoid glioma, a low-grade tumor (WHO grade I) with selective predilection for the $3^{\text {rd }}$ ventricle, thus expanding the group of TTF-1 immunoreactive sellar/parasellar tumors [42].

Using both monoclonal antibodies, Bielle et al. reported in 2015 on 17 cases of such tumors assembled from a multi-institutional study. They found universal immunoreactivity in all of them (17 out of 17) using the SPT24 clone with a 60 to $100 \%$ positive index of tumor cells. When the 8G7G3/1 clone was employed, less intense and variable immunoreactivity was detected in 15 of 17 cases as follows: 5 to 20\% positive cells were observed in 11 cases, 30 to $70 \%$ in 3 cases, and no significant reactivity in 1 [43]. These investigators also demonstrated TTF-1 expression in both the embryonal and adult lamina terminalis of the rat, giving support to the hypothesis of the origin of the chordoid glioma from ependymal cells or tanycytes of the circumventricular vascular organs of the lamina terminalis, including the subfornical organ and the subcommissural organ [43, 71]. In other terms, the so-called chordoid glioma is not a real glioma, and its originary cells are almost always located in the anterior wall of the 3rd ventricle, indicating that its origin is almost always the same.

Almost contemporarily, Hewer et al. reported another case of a TTF-1 immunopositive chordoid glioma, using both the 8G7G3/1 and SPT24 clones. These authors included in the study three new cases of spindle cell oncocytomas, all of which were immunoreactive for TTF-1 with both monoclonal antibodies [44]. In their experience, the immunoreactivity was of variable intensity with the 8G7G3 clone and diffusely strong with the SPT24 clone.

Again, Hewer et al. analyzed seven cases of subependymal giant cell astrocytomas of the tuberous sclerosis complex, which are tumors almost consistently located along the caudate nuclei in the lateral ventricles. They documented diffuse TTF-1 immunoreactivity in these tumors using both monoclonal antibodies. Based on these findings, they proposed a lineage-committed derivation from regional-specific cells related to the medial ganglionic eminence, the ventral septal region, and from the anterior wall of the 3rd ventricle of the developing basal brain, under the regulatory influence of TTF-1 [45].

In 2016, Wang et al. analyzed TTF-1 expression (with the 8G7G3/1 clone) in 3 chordoid gliomas, and included 11 cases of pituicytoma and 23 low-grade astrocytomas (16 pilocytic, 4 diffuse, and 3 pilomyxoid astrocytomas): all chordoid gliomas and all pituicytomas in this series were immunopositive, while all cases of astrocytomas were negative [46].

In 2017, Tauziède-Espariat et al. reported one additional case of a TTF-1 immunoreactive chordoid glioma [72] (the clone used was not available to us), and Garcia-Garcia et al. also reported another case which was TTF-1 immunonegative; again, the clone used was not stated by the reporting authors [73].

Additionally, based on our own (PubMed) and others' computerized search [74, 75] and review of the literature, about 104 cases of chordoid gliomas have been recorded thus far, excluding the series of 16 cases of Rosenberg et al. [76] included in a molecular study, which, at least in part, may have been included in the other cited series of Bielle et al. [43].

However, no TTF-1-expressing CNS embryonal tumor had been reported until now. 
Case 1 of this report, concerning the PNET in a $61 / 2$-year-old girl, is the only one among 24 embryonal CNS neoplasms analyzed in a study to exhibit TTF-1 immunoreactivity, this was prompted by the unexpected expression of TTF-1 in a unique case of monophasic stromal Wilms' tumor metastasis to the lung, which was paradoxically TTF- $1^{+} / \mathrm{WT} 1^{-}$[29]. This TTF-1 immunopositive PNET was the only suprasellar tumor in our series as well.

In case 2 , the embryonal neoplasm in a 36-year-old female was incidentally found, and was also located in the ventral brain at the level of the diencephalon. This TTF-1-expressing embryonal tumor in an adult should alert neurosurgical pathologists about the risk of misdiagnosis, that is, misinterpreting a TTF-1 immunopositive PNET as a metastasis to the brain from any site, especially the lung. As a matter of fact, caution should be taken by the pathologist, especially when dealing with small biopsies, the expression of TTF-1 in a malignant small round cell tumor may obscure the correct diagnosis of an embryonal tumor, primarily in favor of a small-cell (neuroendocrine) carcinoma; this can occur with the auxiliary support of other immunopositive markers of both neuroendocrine nature (such as synaptophysin [77], NSE [78], and neurofilament proteins [79]) and a stem cell marker (such as nestin [80]), which are well-known to be expressed in pulmonary as well as extrapulmonary small cell carcinomas, as they were actually expressed in this case.

Furthermore, in regard to the cytoplasmic reactivity for WT1 as seen in case 2, we would like to remark herein that a cytoplasmic reactivity was repeatedly seen by Bisceglia and Galliani when analyzing this expression in a large series of 100 cases of embryonal soft tissue, visceral (other than nephroblastomas), and CNS tumors. This WT1 cytoplasmic reactivity was observed in $53.8 \%$ of peripheral neuroblastomas, $19.2 \%$ of peripheral PNETs, $35.7 \%$ of medulloblastomas, $50 \%$ of pleuropulmonary blastomas, $60 \%$ of desmoplastic small round cell tumors, $50 \%$ of central PNETs, $40 \%$ of hepatoblastomas, and even (out of the rubric of embryonal tumors) in $22.2 \%$ of synovial sarcomas, with the conclusion in favor of interpreting such a finding as non-specific [53].

The expression of TTF-1 in both these cases was evaluated with the 8G7G3/1 clone.

In summary, as far as primary conventional brain tumors are concerned (Table 1), TTF-1 expression is often seen in high-grade (astrocytic or oligodendrocytic) gliomas when detected with the monoclonal SPT24 antibody, while low-grade astrocytomas and oligodendrogliomas do not express TTF-1 regardless of the antibody clone used. 
Table 1 Primary Brain Tumors investigated for TTF-1 (from the Literature^)

\begin{tabular}{|c|c|c|c|c|c|c|c|c|c|}
\hline \multirow{3}{*}{$\begin{array}{c}\begin{array}{c}\text { Authors } \\
\text { and Reference }\end{array} \\
\text { Year } \\
\text { Monoclonal Ab } \\
\end{array}$} & \multirow{3}{*}{$\begin{array}{c}\begin{array}{l}\text { Zamecnik } \\
\text { et al [36] }\end{array} \\
2004 \\
8 \text { G7G3/1 } \\
\end{array}$} & \multirow{3}{*}{$\begin{array}{c}\begin{array}{c}\text { Prok } \\
\text { and Prayson [37] }\end{array} \\
2006 \\
\mathbf{8 G 7 G 3 / 1} \\
\end{array}$} & \multicolumn{2}{|c|}{$\begin{array}{c}\text { Galloway } \\
\text { and Sim [38] }\end{array}$} & \multirow{3}{*}{$\begin{array}{c}\begin{array}{c}\text { Bisceglia }{ }^{\circ} \text { et al [53] } \\
\text { \& Galliani }{ }^{\circ \circ} \text { et al }[47]\end{array} \\
2010 ; 2011 \\
8 G 7 G 3 / 1 \\
\end{array}$} & \multirow{2}{*}{\multicolumn{2}{|c|}{$\begin{array}{c}\begin{array}{c}\text { Kristensen } \\
\text { et al [40] }\end{array} \\
2011\end{array}$}} & \multirow{2}{*}{\multicolumn{2}{|c|}{$\begin{array}{c}\text { Unal } \\
\text { et al [41] } \\
2014\end{array}$}} \\
\hline & & & \multicolumn{2}{|c|}{2007} & & & & & \\
\hline & & & SPT24 & 8G7G3/1 & & SPT24 & 8G7G3/1 & SPT24 & $8 G 7 G 3 / 1$ \\
\hline $\begin{array}{l}\text { h.g. Astrocytic \& } \\
\text { Oligodendrocytic } \\
\text { Glial Tumors } \\
\end{array}$ & $\begin{array}{l}0 / 33 \\
\text { (g. IV) }\end{array}$ & $\begin{array}{l}0 / 50 \\
\text { (g. IV) }\end{array}$ & $\begin{array}{c}14^{+} / 28 \\
\text { (g. IV) }\end{array}$ & $\begin{array}{l}0 / 28 \\
\text { (g. IV) }\end{array}$ & & $\begin{array}{c}10^{+} / 56 \\
\text { (g. III \& IV) }\end{array}$ & $\begin{array}{c}0 / 56 \\
\text { (g. III \& IV) }\end{array}$ & $\begin{array}{c}4^{+} / 24 \\
\text { (g. III \& IV) }\end{array}$ & $\begin{array}{c}0 / 24 \\
\text { (g. III \& IV) }\end{array}$ \\
\hline $\begin{array}{l}\text { I.g. Astrocytic \& } \\
\text { Oligodendrocytic } \\
\text { Glial Tumors } \\
\end{array}$ & & & & & & $0 / 47$ & $0 / 47$ & $0 / 10$ & $0 / 10$ \\
\hline Ependymomas & $2^{+*} / 27$ & & & & & $1^{+} / 18$ & $0 / 18$ & & \\
\hline Subependymomas & & & & & & & & & \\
\hline $\begin{array}{l}\text { Embryonal tumors } \\
\text { (cPNET \& congeners) }\end{array}$ & $\begin{array}{l}0 / 7 \\
(\mathrm{mb})\end{array}$ & & & & $\begin{array}{c}1^{+* *} / 25 \\
(14 \mathrm{mb} ; 4 \text { s.t. \& } 1 \text { i.m. PNET; } 3 \\
\text { s.t. nb; } 2 \text { pb; } 1 \text { rb) }\end{array}$ & $0 / 8$ & $0 / 8$ & $0 / 1(\mathrm{mb})$ & $0 / 1$ \\
\hline Central neurocytomas & & & & & $0 / 2$ & $1^{+} / 3$ & $0 / 3$ & & \\
\hline Pineocytomas & & & & & $0 / 3$ & $0 / 4$ & $0 / 4$ & & \\
\hline $\begin{array}{l}\text { I.g. Mixed Tumors } \\
\text { (g.g. \& g.n. t.) }\end{array}$ & $\begin{array}{c}0 / 3 \\
\text { (g.g.) }\end{array}$ & & & & & $\begin{array}{c}0 / 4 \\
\text { (g.n.t.) }\end{array}$ & $\begin{array}{c}0 / 4 \\
\text { (g.n.t.) }\end{array}$ & & \\
\hline Meningiomas & & & & & & $0 / 11$ & $0 / 11$ & $0 / 9$ & $0 / 0$ \\
\hline Schwannomas & & & & & & & & $0 / 1$ & $0 / 1$ \\
\hline
\end{tabular}

Abbreviations: $A b=$ Antibody; h.g.= high grade; I.g.= low grade; $c P N E T=$ central PNET (primitive neuroectodermal tumor, currently CNS embryonal tumors); g.g.= ganglioglioma; g.n. t.= glioneuronal tumor; $\mathrm{mb}=$ medulloblastoma; s.t.= supratentorial; i.m= inframedullary; s.t. $\mathrm{nb}=\mathrm{supratentorial} \mathrm{neuroblastoma;} \mathrm{pb=}$ pineoblastoma; $r b=$ retinoblastoma; CNS: central nervous system.

Symbols: ${ }^{\wedge}$ : Excluded from the Table are the TTF- $1^{+}$primary brain tumors of uncertain histogenesis (i.e., chordoid glioma and subependymal giant cell astrocytoma of tuberous sclerosis complex) as well as the TTF- $1^{+}$tumors of the posterior hypophysis; $+=$immunopositive; ${ }^{*}=$ intra $\left(3^{\text {rd }}\right)$ ventricular ependymoma; $* *=$ suprasellar embryonal tumor (PNET); ${ }^{\circ}=$ this study aimed to investigate TTF-1 and WT1 in 100 central and peripheral PNET (from soft tissue, visceral [other than nephroblastoma], and CNS cases) [53]; ${ }^{\circ}=$ this study, including the previous one, and extended to 117 surry embryonal tumors, analyzed the results restricted to TTF1 only. [47]

Parenthetically: In the cited study by Galliani et al. [47] of 92 embryonal tumors from extra-CNS sites (from soft tissue, visceral [other than nephroblastoma]) and 25 primitive neuroectodermal tumors of the CNS (cPNET / CNS embryonal tumors) none was TTF-1 immunoreactive, except for case 1, herein reported, with suprasellar location. Instead, of the 48 cases of nephroblastoma (Wilms tumor) studied for TTF-1 expression, 8 (16.6\%) of them were positive. [29] 
Ependymomas demonstrate occasional immunoreactivity when tested with the SPT24 clone, while no immunostaining is observed with the other clone.

Based on very limited data, subependymomas are negative for TTF- $1\left(0^{+}\right.$of four investigated with the $8 \mathrm{G} 7 \mathrm{G} 3 / 1$ clone).

Meningiomas are usually negative with either clone.

Embryonal tumors of the brain (central PNETs, including medulloblastomas) do not express TTF-1 with either clone (nine cases studied with the SPT24 clone and 40 cases studied with the $8 \mathrm{G} 7 \mathrm{G} 3 / 1$ clone), except for those arising in the diencephalic region as attested by the two cases presented herein.

Differentiated tumors of neuronal lineage (central neurocytomas and pineocytomas) can occasionally express TTF-1 immunopositivity with the SPT24 clone $\left(1^{+}\right.$of 7$)$, while they are negative with the $8 \mathrm{G} 7 \mathrm{G} 3 / 1$ clone $\left(0^{+}\right.$of 12 ).

Low-grade mixed glioneuronal or ganglioglial brain tumors do not express TTF-1 $\left(0^{+}\right.$of 4 studied with the SPT24 clone and $0^{+}$of 11 with the other clone).

Instead, regarding the entire spectrum of TTF-1 immunopositive retrohypophyseal (and infundibular) tumors as well as the so-called chordoid glioma of the 3rd ventricle and SEGAs of the tuberous sclerosis complex, we assert that TTF-1 is consistently detected with both SPT24 and 8G7G3/1 clones, and stronger and more diffuse immunoreactivity is observed with the former clone.

Notably, the notion of TTF-1 immunopositive sellar tumors is not widespread. Several recent such cases have not been so tested [63, 69, 70,81, 82].

We categorically agree with the concept [36] that expression of TTF-1 in brain tumours appears to be a site-specific biomarker, rather than a non-specific tumor marker associated with tumor dedifferentiation.

\section{Conclusions}

Brain tumors (both low-grade and high-grade) of either astrocytic or oligodendrocytic lineage fail to express nuclear TTF-1 immunoreactivity as detected by the $8 \mathrm{G} 7 \mathrm{G} 3 / 1$ clone.

Primary tumors of the posterior pituitary and infundibulum consistently express TTF-1 with both clones.

The so-called chordoid glioma of the $3^{\text {rd }}$ ventricle as well as the SEGA of the tuberous sclerosis complex (notably with limited data for the latter tumor) constantly express TTF-1 with both clones.

TTF-1 expression in suprasellar or periventricular diencephalic embryonal tumors (PNET) is a novelty.

TTF-1 immunopositivity in both primary brain and posterior hypophyseal tumors likely reflects a lineage marker.

TTF-1 expression in a suprasellar, parasellar, diencephalic, or circumventricular $\left(3^{\text {rd }}\right)$ primary brain tumors should be taken into consideration when interpreting metastatic (brain) tumors of uncertain origin. 


\section{Acknowledgments}

Case 1 of this report was previously presented in the session of "Neuropathology" at the 6th SIAPEC National Congress of the Italian Anatomic Pathology Society, held in Palermo, Italy: 27-29 Ottobre, 2011, and was published in abstract form in the proceedings of the Congress (Pathologica. 103 (04):206-207).

\section{Author Contributions}

Michele Bisceglia, MD, Tullio Parracino, MD, and Carlos A. Galliani, MD, were responsible for the study of case 1; Stefano Pizzolitto, MD, Giovanna De Maglio, PhD, and Serena D'Agostini, MD, were responsible for the study of case 2; Elena Minenna, MD, was fully responsible for the bibliographic search and relevant statistical data.

All the authors participated in the study design, and contributed effectively to the writing and/or illustrations of the manuscript.

\section{Competing Interests}

The authors have declared that no competing interests exist.

\section{References}

1. Bingle CD. Thyroid transcription factor-1. Int J Biochem Cell Biol. 1997; 29: 1471-1473.

2. Boggaram V. Thyroid transcription factor-1 (TTF-1/Nkx2.1/TITF1) gene regulation in the lung. Clin Sci (Lond). 2009; 116: 27-35.

3. Kimura S, Hara Y, Pineau T, Fernandez-Salguero $\mathrm{P}$, Fox $\mathrm{CH}$, Ward JM, et al. The T/ebp null mouse: thyroid-specific enhancer-binding protein is essential for the organogenesis of the thyroid, lung, ventral forebrain, and pituitary. Genes Dev. 1996; 10: 60-69.

4. Lazzaro D, Price M, de Felice M, Di Lauro R. The transcription factor TTF-1 is expressed at the onset of thyroid and lung morphogenesis and in restricted regions of the foetal brain. Development. 1991; 113: 1093-1104.

5. Minoo P, Hamdan H, Bu D, Warburton D, Stepanik P, delemos R. TTF-1 regulates lung epithelial morphogenesis. Dev Biol. 1995; 172: 694-698.

6. DeFelice $M$, Silberschmidt $D$, DiLauro $R$, Xu Y, Wert SE, Weaver TE, et al. TTF-1 phosphorylation is required for peripheral lung morphogenesis, perinatal survival, and tissuespecific gene expression. J Biol Chem. 2003; 278: 35574-35583.

7. Maeda Y, Davé V, Whitsett JA. Transcriptional control of lung morphogenesis. Physiol Rev. 2007; 87: 219-244.

8. Ogasawara M, Shigetani $Y$, Suzuki S, Kuratani S, Satoh N. Expression of thyroid transcription factor-1 (TTF-1) gene in the ventral forebrain and endostyle of the agnathan vertebrate, Lampetra japonica. Genesis. 2001; 30: 51-58.

9. Kaji T, Nonogaki K. Role of homeobox genes in the hypothalamic development and energy balance. Front Biosci (Landmark Ed). 2013; 18: 740-747.

10. Kimura S, Ward JM, Minoo P. Thyroid-specific enhancer-binding protein/thyroid transcription factor 1 is not required for the initial specification of the thyroid and lung primordia. Biochimie. 1999; 81: 321-327. 
11. Kim MS, Hur MK, Son YJ, Park JI, Chun SY, D'Elia AV, et al. Regulation of pituitary adenylate cyclase-activating polypeptide gene transcription by TTF-1, a homeodomain-containing transcription factor. J Biol Chem. 2002; 277: 36863-36871.

12. Son YJ, Hur MK, Ryu BJ, Park SK, Damante G, D'Elia AV, et al. TTF-1, a homeodomaincontaining transcription factor, participates in the control of body fluid homeostasis by regulating angiotensinogen gene transcription in the rat subfornical organ. J Biol Chem. 2003; 278: 27043-27052.

13. Sussel L, Marin O, Kimura S, et al. Loss of Nkx2.1 homeobox gene function results in a ventral to dorsal molecular respecification within the basal telencephalon: evidence for a transformation of the pallidum into the striatum. Development. 1999; 126: 3359-3370.

14. Marin O, Anderson SA, Rubinstein JL. Origin and molecular specification of striatal interneurons. J Neurosci. 2000; 20: 6063-6076.

15. Flandin $\mathrm{P} 1$, Kimura $\mathrm{S}$, Rubenstein $\mathrm{JL}$. The progenitor zone of the ventral medial ganglionic eminence requires $\mathrm{Nkx2-1}$ to generate most of the globus pallidus but few neocortical interneurons. J Neurosci. 2010; 30: 2812-2823.

16. Lee BJ, Cho GJ, Norgren RB Jr, Junier MP, Hill DF, Tapia V, et al. TTF-1, a homeodomain gene required for diencephalic morphogenesis, is postnatally expressed in the neuroendocrine brain in a developmentally regulated and cell-specific fashion. Mol Cell Neurosci. 2001; 17: 107-126.

17. Ordóñez NG. Thyroid transcription factor-1 is a marker of lung and thyroid carcinomas. Adv Anat Pathol. 2000; 7: 123-127.

18. Kaufmann O, Dietel M. Thyroid transcription factor-1 is the superior immunohistochemical marker for pulmonary adenocarcinomas and large cell carcinomas compared to surfactant proteins A and B. Histopathology. 2000; 36: 8-16.

19. Lau SK, Luthringer DJ, Eisen RN. Thyroid transcription factor-1: a review. Appl Immunohistochem Mol Morphol. 2002; 10: 97-102.

20. Zhang $P$, Zuo H, Nakamura $Y$, Nakamura $M$, Wakasa $T$, Kakudo K. Immunohistochemical analysis of thyroid-specific transcription factors in thyroid tumors. Pathol Int. 2006; 56: 240245.

21. Ordóñez NG. Value of thyroid transcription factor-1 immunostaining in tumor diagnosis: a review and update. Appl Immunohistochem Mol Morphol. 2012; 20: 429-444.

22. Kaufmann $O$, Dietel $M$. Expression of thyroid transcription factor-1 in pulmonary and extrapulmonary small cell carcinomas and other neuroendocrine carcinomas of various primary sites. Histopathology. 2000; 36: 415-420.

23. Matoso A, Singh K, Jacob R, Greaves WO, Tavares R, Noble L, et al. Comparison of thyroid transcription factor-1 expression by 2 monoclonal antibodies in pulmonary and nonpulmonary primary tumors. Appl Immunohistochem Mol Morphol. 2010; 18: 142-149.

24. Bisceglia M, Galliani C, Rosai J. TTF-1 expression in breast carcinoma - the chosen clone matters. Am J Surg Pathol. 2011; 35: 1087-1088.

25. Agoff SN, Lamps LW, Philip AT, Amin MB, Schmidt RA, True LD, et al. Thyroid transcription factor-1 is expressed in extrapulmonary small cell carcinomas but not in other extrapulmonary neuroendocrine tumors. Mod Pathol. 2000; 13: 238-242. 
26. Yamamoto J, Ohshima K, Nabeshima K, Ikeda S, Iwasaki H, Kikuchi M. Comparative study of primary mammary small cell carcinoma, carcinoma with endocrine features and invasive ductal carcinoma. Oncol Rep. 2004; 11: 825-831.

27. Yun JP, Zhang MF, Hou JH, Tian QH, Fu J, Liang XM, et al. Primary small cell carcinoma of the esophagus: clinicopathological and immunohistochemical features of 21 cases. BMC Cancer. 2007; 7: 38.

28. Wang W, Epstein Jl. Small cell carcinoma of the prostate. A morphologic and immunohistochemical study of 95 cases. Am J Surg Pathol. 2008; 32: 65-71.

29. Bisceglia M, Ragazzi M, Galliani CA, Lastilla G, Rosai J. TTF-1 expression in nephroblastoma. Am J Surg Pathol. 2009; 33: 454-461.

30. Compérat E, Zhang F, Perrotin C, Molina T, Magdeleinat P, Marmey B, et al. Variable sensitivity and specificity of TTF-1 antibodies in lung metastatic adenocarcinoma of colorectal origin. Mod Pathol. 2005; 18: 1371-1376.

31. Siami K, McCluggage WG, Ordonez NG, Euscher ED, Malpica A, Sneige N, et al. Thyroid transcription factor-1 expression in endometrial and endocervical adenocarcinomas. Am J Surg Pathol. 2007; 31: 1759-1763.

32. Deavers MT. Immunohistochemistry in gynecologic pathology. Arch Pathol Lab Med. 2008; 132: $175-180$.

33. Robens J, Goldstein L, Gown AM, Schnitt SJ. Thyroid transcription factor-1 expression in breast carcinomas. Am J Surg Pathol. 2010; 34: 1881-1885.

34. Klingen TA, Chen $Y$, Suhrke $P$, Stefansson IM, Gundersen MD, Akslen LA. Expression of thyroid transcription factor-1 is associated with a basal-like phenotype in breast carcinomas. Diagn Pathol. 2013; 8: 80.

35. Casteillo F, Fournel P, Da Cruz V, Karpathiou G, Boutet C, Jacquin JP, et al. TTF-1-positive Metastatic Endometrioid Carcinoma: A Case Report and Review of Literature of a Potential Diagnostic Pitfall. Appl Immunohistochem Mol Morphol. 2017. doi: 10.1097/PAI.0000000000000539.

36. Zamecnik J, Chanova M, Kodet R. Expression of thyroid transcription factor 1 in primary brain tumours. J Clin Pathol. 2004; 57: 1111-1113.

37. Prok AL, Prayson RA. Thyroid transcription factor-1 staining is useful in identifying brain metastases of pulmonary origin. Ann Diagn Pathol. 2006; 10: 67-71.

38. Galloway M, Sim R. TTF-1 staining in glioblastoma multiforme. Virchows Arch. 2007; 451: 109111.

39. Lee EB, Tihan T, Scheithauer BW, Zhang PJ, Gonatas NK. Thyroid transcription factor 1 expression in sellar tumors: a histogenetic marker? J Neuropathol Exp Neurol. 2009; 68: 482488.

40. Kristensen $\mathrm{MH}$, Nielsen $\mathrm{S}$, Vyberg $\mathrm{M}$. Thyroid transcription factor-1 in primary CNS tumors. Appl Immunohistochem Mol Morphol. 2011; 19: 437-443.

41. Unal B, Yildirim S, Sezer C, Süren D. TTF-1 may not be a reliable marker for differentiating metastasis from brain tumors. Turk Patoloji Derg. 2014; 30: 201-205.

42. Michotte A, Van Der Veken J, Huylebrouck M, Duerinck J, D'Haens J, Hoorens A. Expression of thyroid transcription factor 1 in a chordoid glioma. J Neurol Sci. 2014; 346: 362-363. 
43. Bielle F, Villa C, Giry M, Bergemer-Fouquet AM, Polivka M, Vasiljevic A, et al. Chordoid gliomas of the third ventricle share TTF-1 expression with organum vasculosum of the lamina terminalis. Am J Surg Pathol. 2015; 39: 948-956.

44. Hewer E, Beck J, Kellner-Weldon F, Vajtai I. Suprasellar chordoid neoplasm with expression of thyroid transcription factor 1: evidence that chordoid glioma of the third ventricle and pituicytoma may form part of a spectrum of lineage-related tumors of the basal forebrain. Hum Pathol. 2015; 46: 1045-1049.

45. Hewer E, Vajtai I. Consistent nuclear expression of thyroid transcription factor 1 in subependymal giant cell astrocytomas suggests lineage-restricted histogenesis. Clin Neuropathol. 2015; 34: 128-131.

46. Wang J, Liu Z, Du J, Cui Y, Fang J, Xu L, Li G. The clinicopathological features of pituicytoma and the differential diagnosis of sellar glioma. Neuropathology. 2016; 36: 432-440.

47. Galliani CA, Bisceglia M, Lastilla G, Parafioriti A, Vita G, Rosai J. TTF-1 in embryonal tumors: an immunohistochemical study of 117 cases. Am J Surg Pathol. 2011; 35: 1422-1425.

48. Louis DN, Ohgaki H, Wiestler OD, Cavenee WK. Embryonal tumors (Ch. 8). In: WHO Classification of Tumours of the Central Nervous System. Revised 4th edition. World Health Organ Tumors. Lyon, France: IARCpress; 2016; p. 183-212.

49. Gessi M, Bisceglia M, Lauriola L, Giangaspero F. Cerebral neuroblastoma in adults: report of three cases. Proceedings of the XXI Congress of the European Society of Pathology, 2007, September 8-13 Istanbul (Turkey). Virchows Archiv 2007; 451: PP4-213 (A).

50. Gessi M, Setty P, Bisceglia M, zur Muehlen A, Lauriola L, Waha A, et al. Supratentorial primitive neuroectodermal tumors of the central nervous system in adults: molecular and histopathologic analysis of 12 cases. Am J Surg Pathol. 2011; 35: 573-582.

51. Nakamura K, Kimura S, Yamazaki M, Kawaguchi A, Inoue K, Sakai T. Immunohistochemical analyses of thyroid-specific enhancer-binding protein in the fetal and adult rat hypothalami and pituitary glands. Brain Res Dev Brain Res. 2001; 130: 159-166.

52. Kim JG, Nam-Goong IS, Yun CH, Jeong JK, Kim ES, Park JJ, et al. TTF-1, a homeodomaincontaining transcription factor, regulates feeding behavior in the rat hypothalamus. Biochem Biophys Res Commun. 2006; 349: 969-975.

53. Bisceglia M, Galliani C, Lastilla G, Rosai J. TTF-1 and WT1 expression in embryonal soft tissue, visceral, and central nervous system tumors. An immunohistochemical study of 100 cases. Proceedings of the 5th SIAPEC Annual Italian Congress of Anatomic Pathology, 2010, September 21-25, Bologna (Italy). Pathologica. 2010; 102: 253-254.

54. Mete O, Lopes MB, Asa SL. Spindle cell oncocytomas and granular cell tumors of the pituitary are variants of pituicytoma. Am J Surg Pathol. 2013; 37: 1694-1699.

55. Scheithauer BW, Swearingen B, Whyte ET, Auluck PK, Stemmer-Rachamimov AO. Ependymoma of the sella turcica: a variant of pituicytoma. Hum Pathol. 2009; 40: 435-440.

56. Saeed Kamil Z, Sinson G, Gucer H, Asa SL, Mete O. TTF-1 expressing sellar neoplasm with ependymal rosettes and oncocytic change: mixed ependymal and oncocytic variant pituicytoma. Endocr Pathol. 2014; 25: 436-438.

57. El Hussein S, Vincentelli C. Pituicytoma: Review of commonalities and distinguishing features among TTF-1 positive tumors of the central nervous system. Ann Diagn Pathol. 2017; 29: 5761. 
58. Jiang B, Shi X, Fan C. Sellar and suprasellar granular cell tumor of the neurohypophysis: A rare case report and review of the literature. Neuropathology. 2018; 38: 293-299.

59. Roncaroli F, Scheithauer BW, Cenacchi G, Horvath E, Kovacs K, Lloyd RV, et al. Santi M, Yates AJ. 'Spindle cell oncocytoma' of the adenohypophysis: a tumor of folliculostellate cells? Am J Surg Pathol. 2002; 26: 1048-1055.

60. Kleinschmidt-DeMasters BK, Lopes MB. Update on hypophysitis and TTF-1 expressing sellar region masses. Brain Pathol. 2013; 23: 495-514.

61. Yoshimoto T, Takahashi-Fujigasaki J, Inoshita N, Fukuhara N, Nishioka H, Yamada S.TTF-1positive oncocytic sellar tumor with follicle formation/ependymal differentiation: nonadenomatous tumor capable of two different interpretations as a pituicytoma or a spindle cell oncocytoma. Brain Tumor Pathol. 2015; 32: 221-227.

62. Vuong HG, Kondo T, Tran TM, Oishi N, Nakazawa T, Mochizuki K, et al. Spindle cell oncocytoma of adenohypophysis: Report of a case and immunohistochemical review of literature. Pathol Res Pract. 2016; 212: 222-225.

63. Wang S, Zong W, Li Y, Wang B, Ke C, Guo D. Pituitary Ependymoma: A Case Report and Review of the Literature. World Neurosurg. 2018; 110: 43-54.

64. Vajtai I, Beck J, Kappeler A, Hewer E. Spindle cell oncocytoma of the pituitary gland with follicle-like component: organotypic differentiation to support its origin from folliculo-stellate cells. Acta Neuropathol. 2011; 122: 253-258.

65. Mete O, Lopes MBS, Roncaroli F, Tihan T, Yamada S. Tumors of the posterior pituitary. In: Lloyd RV, Osamura RY, Klöppel G, Rosai J, editors. WHO Classification of Tumours of Endocrine Organs. World Health Organ Tumors. Lyon: IARC press. 2017; p. 52-54.

66. Mete O, Lopes MB. Overview of the 2017 WHO Classification of Pituitary Tumors. Endocr Pathol. 2017; 28: 228-243.

67. Lopes MBS. The 2017 World Health Organization classification of tumors of the pituitary gland: a summary. Acta Neuropathol. 2017; 134: 521-535.

68. Shibuya M. Welcoming the new WHO classification of pituitary tumors 2017: Revolution in TTF-1-positive posterior pituitary tumors. Brain Tumor Pathol. 2018; 35: 62-70.

69. Parish JM, Bonnin JM, Goodman JM, Cohen-Gadol AA. Intrasellar ependymoma: clinical, imaging, pathological, and surgical findings. J Clin Neurosci. 2015; 22: 638-641.

70. Lee JS, Cho KH, Hong EK, Shin SH. Pituitary Ependymoma, 10-Year Follow-Up after Partial Resection and Radiation Therapy. Brain Tumor Res Treat. 2017; 5: 94-98.

71. Leeds NE, Lang FF, Ribalta T, Sawaya R, Fuller GN. Origin of chordoid glioma of the third ventricle. Arch Pathol Lab Med. 2006; 130: 460-464.

72. Tauziède-Espariat A, Robert G, de Cremoux P, Polivka M. [A case report of chordoid glioma with unusual features: Immunohistochemical and molecular findings and differential diagnoses]. [Article in French] Ann Pathol. 2017; 37: 151-157.

73. Garcia-Garcia S, Aldecoa I, Caral LA, Ferrer E, Ribalta T, González-Sánchez JJ. Management in chordoid glioma: Avoiding the pitfalls in this rare and challenging entity. Neurol India. 2017; 65: 808-813.

74. Morais BA, Menendez DF, Medeiros RS, Teixeira MJ, Lepski GA. Chordoid glioma: Case report and review of the literature. Int J Surg Case Rep. 2015; 7C: 168-171. 
75. Huo CW, Rathi V, Scarlett A, Galanos J, Wang YY. The trans-laminar terminalis approach reduces mortalities associated with chordoid glioma resections: A case report and a review of 20 years of literature. J Clin Neurosci. 2018; 47: 43-55.

76. Rosenberg S, Simeonova I, Bielle F, Verreault M, Bance B, Le Roux I, et al. A recurrent point mutation in PRKCA is a hallmark of chordoid gliomas. Nat Commun. 2018; 9: 2371.

77. Leube RE, Wiedenmann B, Franke WW. Differentiation markers as an aid in the histological diagnosis of small-cell carcinoma of the lung: synopsis of intermediate filament protein and synaptophysin expression. Klin Wochenschr. 1988; 66 Suppl 11: 80-86.

78. Cooper EH. Neuron specific enolase: a marker of (small cell) cancers of neuronal and neuroendocrine origin. Biomed Pharmacother. 1985; 39: 165-166.

79. Bergh J, Nilsson K, Dahl D, Andersson L, Virtanen I, Lehto VP. Expression of intermediate filaments in established human lung cancer cell lines. An indicator of differentiation and derivation. Lab Invest. 1984; 51: 307-316.

80. Takakuwa O, Maeno K, Kunii E, Ozasa H, Hijikata H, Uemura T, et al. Involvement of intermediate filament nestin in cell growth of small-cell lung cancer. Lung Cancer. 2013; 81: 174-179.

81. Chakraborti S, Mahadevan A, Govindan A, Sridhar K, Mohan NV, Satish IR, et al. Pituicytoma: report of three cases with review of literature. Pathol Res Pract. 2013; 209: 52-58.

82. Piccirilli M, Maiola V, Salvati M, D'Elia A, Di Paolo A, Campagna D, et al. Granular cell tumor of the neurohypophysis: a single-institution experience. Tumori. 2014; 100: 160e-164e.

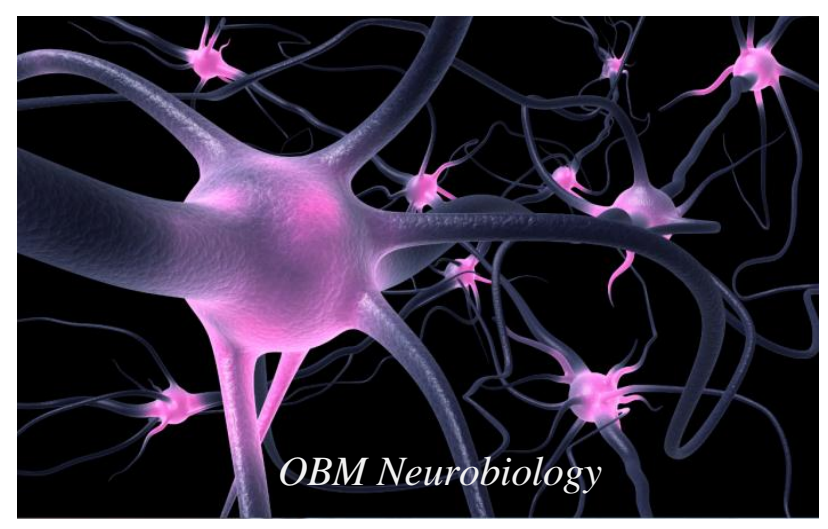

Enjoy OBM Neurobiology by:

1. Submitting a manuscript

2. Joining volunteer reviewer bank

3. Joining Editorial Board

4. Guest editing a special issue

For more details, please visit:

http://www.lidsen.com/journals/neurobiology 